\title{
KAJIAN SEMIOTIKA ROLAND BARTHES
}

\author{
Al Fiatur Rohmaniah'1) \\ 1)UIN Walisongo Semarang \\ 1)alfirohmaniah09@gmail.com
}

\begin{abstract}
Abstrak. Semiotik merupakan metode untuk mengkaji cara kerja dan fungsi tanda (sign). Dalam kaitannya dengan objek penelitian, teks merupakan suatu konstruksi dari unsur tanda-tanda. Dalam tradisi semiotika, komunikasi pada intinya dipandang sebagai mediasi atau pertukaran tanda-tanda secara intersubjektif. Sebagai teori penafsiran, semiotik tidak sekedar menafsirkan teks, memperlakukan teks sebagai teks, tetapi membuat teks berbicara, bahkan tentang hal di luar dirinya. Pendekatan yang digunakan peneliti adalah semiotika Roland Barthes yang mengembangkan gagasan-gagasan Ferdinand de Saussure dan mencoba menerapkan kajian tandatanda secara lebih luas. Pada praktinya peneliti mengggunakan kajian semiotik untuk menganalisis teks dan visual yang ada pada media sosial Instagram @dkksemarang adalah akun resmi dari Dinas Kesehatan Kota Semarang. Pada kondisi pandemi Covid19 yang identik dengan upaya memutus rantai penyebaran virus dan mendukung program vaksinasi.
\end{abstract}

Kata Kunci: Semiotika, Roland Barthes, Covid-19.

Abstract. Semiotics is a method for studying the workings and functions of signs. In the object of research, the text is a construction of elements of signs. In the semiotic tradition, communication is seen as a mediation or intersubjective exchange of signs. As a theory, semiotics does not deal with texts, treats texts as texts, but makes texts speak, even about things outside of themselves. The approach used by the researcher is the semiotics of Roland Barthes who develops the ideas of Ferdinand de Saussure and tries to apply the study of signs more broadly. In practice, researchers use semiotic studies to analyze text and visuals on social media Instagram @dkksemarang is the official account of the Semarang City Health Office. In the conditions of the Covid-19 pandemic, which is identical to efforts to break the chain of virus spread and support vaccination programs.

Keywords: Semiotics, Roland Barthes, Covid-19.

\section{PENDAHULUAN}

Semiotika merupakan suatu ilmu yang mengkaji tanda dalam kehidupan manusia. Pada dasarnya manusia memiliki kemampuan untuk mencari makna pada setiap gejala sosial yang terjadi di sekitarnya. ${ }^{1}$ Dalam tradisi semiotika, komunikasi pada intinya dipandang sebagai mediasi atau pertukaran tanda-tanda secara intersubjektif. Komunikasi menjelaskan dan mengembangkan penggunaan bahasa dan sistem-sistem tanda lainnya dalam bentuk pertukaran (mediasi) antar perspektif yang bervariasi. Problematika komunikasi dalam paradigma

\footnotetext{
${ }^{1}$ Hoed, H Benny. 2014. Semiotika dan Dinamika Sosial Budaya. Depok: Komunitas Bambu.
} 
Semiotika merupakan problematika representasi dan transmisi makna, dalam hal terjadinya gap antara subjektivitas yang coba di atasi melalui penggunaan sistem tanda yang disepakati.

John Locke seorang filsuf dan dokter medis berkebangsaan Inggris merupakan sosok yang cukup berhasil mempopulerkan Semiotika yang ia sebut sebagai doktrin tanda-tanda. Semiotika dipahami sebagai satu dari tiga cabang ilmu pengetahuan disamping Physica (pengetahuan atau filsafat) dan Practica (metode dan keterampilan). Semiotika disepadankan dengan logika yang membuka ruang terjadinya komunikasi melalui proses signifikansi ide. ${ }^{2}$

Sudjiman (1992 menyatakan bahwa semiotika ialah studi tentang tanda dan segala yang berhubungan dengannya, meliputi cara berfungsinya, hubungannya dengan tanda-tanda lain, pengirimannya, dan penerimaannya bagi yang menggunakannya. Dalam perspektif yang lebih luas sebagai sebuah teori, semiotika berarti studi sistematis tentang produksi dan interpretasi tanda, cara kerjanya, dan manfaatnya bagi kehidupan manusia. ${ }^{3}$

Teori komunikasi semiotik tampak masuk-akal dan aplikatif melalui pandangan bahwa komunikasi paling mudah ketika kita berbagi bahasa yang sama, bahwa kata-kata dapat memiliki arti yang berbeda bagi orang yang berbeda sehingga kegagalan komunikasi adalah bahaya yang konstan, bahwa makna sering disampaikan secara tidak langsung atau secara halus (terselubung) melalui aspek perilaku yang mungkin luput dari perhatian, dan bahwa ide-ide tertentu lebih mudah diungkapkan melalui media. Di sisi lain, semiotika tampak menarik, berwawasan, atau mungkin tidak masuk akal bagi orang biasa ketika ia menantang kepercayaan umum, seperti pandangan bahwa ide itu berada di benak seseorang, bahwa kata-kata memiliki makna yang benar, bahwa makna dapat dibuat eksplisit, komunikasi itu adalah tindakan sukarela, dan pendapat bahwa tanda dan media komunikasi merupakan alat untuk mewakili dan berbagi pemikiran pihak tertentu. ${ }^{4}$

\section{METODE PENELITIAN}

Peneliti menggunakan metode penelitian kualitatif. Bogdan dan Taylor mendefinikasn metode penelitian kualitatif sebagai prosedur penelitian yang menghasilkan data deskriptif berupa kata-kata tertulis atau lisan dari orang-orang dan perilaku yang diamati. ${ }^{5}$ Pada penelitian

2 Rusyad, Daniel. Landasan Teoritis Tradisi Semiotika Di Dalam Al-Qur'an Paradigma Ilmu Komunikasi Dalam Perspektif Islam. h.4.

3 Setiawan, Kodrat Eko Putro. 2019. Strategi Ampuh Memahami Makna Puisi. Teori Semiotika Michael Riffaterre dan Penerapannya. Cirebon: Eduvision. h.21.

4 Rusyad, Daniel. Landasan Teoritis Tradisi Semiotika Di Dalam Al-Qur'an Paradigma Ilmu Komunikasi Dalam Perspektif Islam. h.5.

5 Moleong, Lexy J. 2002. Metode Penelitian Kualitatif. Bandung: PT Remaja Rosdakarya. Hal. 3. 
kualitatif, Sumber data merupakan hal yang wajib diperoleh dalam penelitian, karena melalui sumber data yang tepat maka penelitian akan berhasil dengan baik. ${ }^{6}$ bentuk data berupa kalimat atau narasi dari subjek atau responden penelitian yang diperoleh melalui suatu teknik pengumpulan data kemudian dianalisis sehingga dapat menghasilkan temuan yang akan menjawab pertanyaan peneliti yang sedang diajukan. ${ }^{7}$ Pendekatan yang digunakan peneliti adalah semiotika. Semiotika adalah ilmu tentang tanda, Roland Barthes mengembangkan gagasan-gagasan Ferdinand de Saussure dan mencoba menerapkan kajian tanda-tanda secara lebih luas. Pada praktinya peneliti media mengggunakan kajian semiotik untuk menganalisis teks dan visual yang ada pada ${ }^{8}$ media sosial Instagram @dkksemarang adalah akun resmi dari Dinas Kesehatan Kota Semarang. Pada kondisi pandemi Covid-19 yang identik dengan upaya memutus rantai penyebaran virus dan mendukung program vaksinasi.

\section{HASIL PENELITIAN DAN PEMBAHASAN}

\section{a. Definisi Semiotik}

Kata semiotika berasal dari kata Yunani "Semeion" artinya Sign (tanda). Semiotika merupakan cabang ilmu yang mengkaji tanda dan proses yang berhubungan dengan tanda seperti system tanda dan proses yang berlaku bagi penggunaan tanda. Zoest (1993) memberikan lima ciri dari tanda. (1) tanda harus dapat diamati agar dapat berfungsi sebagai tanda. (2) tanda harus bisa ditangkap merupakan syarat mutlak. (3) merujuk pada sesuatu yang lain. (4) tanda memiliki sifat representatif dan sifat ini mempunyai hubungan langsung dengan sifat interpretatif. (5) sesuatu hanya dapat merupakan tanda atas dasar satu dan lain. ${ }^{9}$

Dalam kerangka ilmu pengetahuan, semiotik adalah metode untuk mengkaji cara kerja dan fungsi tanda (sign). Dalam kaitannya dengan objek penelitian, teks merupakan suatu konstruksi dari unsur tanda-tanda. Keterkaitan antar-tanda itulah yang mampu memberi makna yang tepat. Ferdinand de Saussure (Course in General Linguistics) menambahkan, semiotik merupakan ilmu yang mengkaji tanda sebagai bagian dari kehidupan sosial.10

${ }^{6}$ Setiadi, Gatut, and Nurma Yuwita. "PENGEMBANGAN MODUL MATA KULIAH BAHASA INDONESIA MENGGUNAKAN MODEL ADDIE BAGI MAHASISWA IAI SUNAN KALIJOGO MALANG”. Akademika : Jurnal Manajemen Pendidikan Islam 2, no. 2 (December 3, 2020): 200-217. Accessed April 30, 2021.

https://ejournal.iaiskjmalang.ac.id/index.php/akad/article/view/207.

${ }^{7}$ Heridansyah, Haris. 2012. Metode Penelitian Kualitatif untuk Ilmu-Ilmu Sosial. Jakarta: Salemba Humanika. Hal: 116.

8 Stokes, Jane. 2006. How To Do Media and Cultural Studies: Panduan untuk Melaksanakan Penelitian dalam Kajian Media dan Budaya. Bandung: Mizan Media Utama. Hal 76.

9 Lantowa, Jafar. 2017. Semiotika Teori, Metode, dan Penerapannya dalam Penelitian Sastra. Yogyakarta: Deepublish. h.1.

10 Yasraf, Amir Piliang. Semiotika sebagai Metode dalam Penelitian Desain, dalam Christomy dan Untung Yuwono, h. 88. 
Semiotik memperlakukan teks sebagai kumpulan tanda. Dengan semiotik dapat diketahui cara kerja dan fungsi tanda. Dengan pendekatan ini akan menghasilkan penafsiran yang liar, sehingga makna terdalam dan tersembunyi dalam satu teks (objek penelitian) dapat tersingkap.

Sebagai teori penafsiran, semiotik tidak sekedar menafsirkan teks, memperlakukan teks sebagai teks, tetapi membuat teks berbicara, bahkan tentang hal di luar dirinya. Karena, teks tidak bisa dipahami hanya dengan membacanya melalui makna yang sudah paten, mapan dan menjadi kesepakatan banyak orang dari waktu ke waktu (konvensi sosial, social convention). Tetapi perlu juga melihat qarinah (penjelas) yang berada di luar teks. Qarinah bisa berupa kondisi politik, sosial, tradisi atau budaya, yang mengiringi lahirnya satu teks. ${ }^{11}$

Semiotik sebagai metode pembacaan menjadi sangat mungkin digunakan dalam mengkaji teks, mengingat ada kecenderungan dewasa ini untuk memandang berbagai wacana sosial, politik, ekonomi, budaya, seni, dan tentu saja teks sebagai fenomena bahasa. semiotik, bila seluruh praktik sosial dapat dianggap sebagai fenomena bahasa, ia dapat pula dipandang sebagai tanda.

Teks dibangun di atas struktur bahasa yang terdiri dari tanda atau kode (sign). Bahasa, menurut Pabottingi, selalu bersinggungan atau tidak pernah lepas dari politik. Berbahasa, mulai dari pemilihan dialek, pemakaian kata, penekanan pengertian tertentu atas kata, sampai tidak berbahasa (pemilihan sikap untuk tidak berbahasa) sekalipun, merupakan sikap politik.

Sedangkan tanda, seperti dikemukakan Volosinov: wherever a sign is present, ideology is present too. Everything ideological prossesses e semiotic value. Tanda selalu menghadirkan ideologi di dalamnya, serta memiliki nilai semiotik. Sementara ideologi, seperti dikatakan Francisco Budi Hardiman, dapat meliputi segala bidang, baik bidang praxis politis maupun bidang teoretis ilmiah. ${ }^{12}$

\section{b. Sejarah Lahirnya Ilmu Semiotik}

Dunia modern mengakui bahwa tokoh utama peletak dasar semiotik adalah Ferdinand De Saussure (1857-1913). la seorang pengajar linguistik umum di Universitas Jenewa pada tahun 1906. Dalam Cours de Linguistique General, kumpulan catatan-catatan kuliahnya (1916), Saussure memperkenalkan semiotik sebagai ilmu analisis tanda (sign) atau studi tentang bagaimana sistem pertandaan (signification) berfungsi, dan bagaimana cara kerjanya. ${ }^{13}$

11 Ali Romdhoni. 2004. Ushul al-Fiqh dan Semiotika Post-Strukturalis (Koran Amanat IAIN Walisongo, edisi 102/November 2004). h.20.

12 Sobur, Alex. Analisis Teks Media. h.14.

13 Ali Romdhoni. 2004. Ushul al-Fiqh dan Semiotika Post-Strukturalis. h.20. 
Menurut Art Van Zoest (1993), senada dengan Saussure, semiotik merupakan cabang ilmu. Namun demikian, menurut Rahayu Surtiati Hidayat, semiotik tidak dapat disebut bidang ilmu, karena fungsinya adalah sebagai alat analisis, cara mengurai suatu gejala. Karena itu, sebagian orang menganggap semiotik sebagai 'ancangan' atau pendekatan (approach). Beberapa pakar yang lain memahaminya sebagai metode (method).14

Sebagaimana tradisi lainnya dalam ilmu komunikasi, Semiotika memiliki akar klasik (Manetti: 1993), tokoh-tokoh penting yang pertama kali mengenalkan Semiotika di antaranya Augustine (397), Albertus Magnus (abad 13), Hobbes (1640) dan John Locke (1690). Adapun dua tokoh sentral yang berjasa dalam pengembangan kajian Semiotika kontemporer adalah Ferdinand De Saussure (1857-1913), seorang ahli bahasa berkebangsaan Swiss dan Charles Sanders Peirce (1839-1914), seorang filsuf berkebangsaan Amerika Serikat. Keduanya berjasa dalam memberikan landasan paradigmatic Semiotika dari dua disiplin berbeda (linguistik dan filsafat) yang dalam perkembangannya mengilhami teori-teori komunikasi, bahasa, wacana, interpretasi, budaya dan media. ${ }^{15}$

Alex Sobur dalam buku Analisis Teks Medianya menyebutkan bahwa semiotik modern memiliki dua bapak, Charles Sanders Pierce (1834-1914) dan Ferdinand de Saussure (18571913). Meskipun masa hidup kedua tokoh ini hampir bersamaan dan memungkinkan untuk saling bertemu, tetapi keduanya tidak saling mengenal satu sama lainnya. ${ }^{16}$

Pierce berkebangsaan Amerika dan Saussure berkebangsaan Perancis. Pierce seorang ahli filsafat dan ahli logika, sementara Saussure adalah cikal bakal kemunculan linguistik umum. Sementara menurut Rahayu Surtiati Hidayat, Saussure memang yang pertama kali mencetuskan gagasan untuk melihat bahasa sebagai sistem tanda (sign). Namun dia sebenarnya tidak pernah berpretensi (berkeinginan) menjadi semiotikus atau semiotisian, karena pusat minatnya adalah bahasa. ${ }^{17}$

Model trikotomi Pierce, proses pemaknaan tanda mengikuti tiga tahap yaitu 1. pesepsi indrawi atau representamen (misalnya asap yang terlihat dari jauh), 2. perujukan asap pada objek (peristiwa kebakaran yang tidak dialami langsung), dan 3. pembentukan interpretan (penafsiran itu pertokoan di daerah "X"). dapat kita lihat bahwa proses 2 dan 3 terjadi dalam oikiran seseorang, sedangkan 1 terjadi karena terindra oleh sesorang. Menurut teori semiotik ini,

14 Rahayu, Surtiati Hidayat. Semiotik dan Bidang Ilmu. h.77.

15 Rusyad, Daniel. Landasan Teoritis Tradisi Semiotika Di Dalam Al-Qur'an Paradigma Ilmu Komunikasi Dalam Perspektif Islam.

16 Sobur, Alex. Analisis Teks Media. h.14.

17 Romdhoni, Ali. 2016. Semioltik Metodologi Penelitian. Depok: Literatur Nusantara. h. 14 
berdasarkan representamennya, kita dapat membedakan tiga jenis tanda, yaitu indeks, ikon, dan lambang. 18

Saussure juga mengakui bahwa bahasa bukanlah satu-satunya sistem tanda, sehingga dia mengusulkan semiologi sebagai kajian tanda dan bukan bahasa. Saussure memperkenalkan semiologi atau semiotik sebagai ilmu analisis tanda, atau studi tentang bagaimana sistem penandaan berfungsi dan cara kerjanya. Kalau Saussure memperkenalkan semiotik sebagai ilmu analisis tanda dan menganggap bahasa sebagai sistem tanda; maka Pierce mengusulkan kata 'semiotik' sebagai sinonim kata logika. Menurut Pierce, logika harus mempelajari bagaimana orang bernalar. Penalaran itu, menurut hipotesis teori Pierce yang mendasar, dilakukan melalui tanda-tanda. Dengan tanda- tanda, memungkinkan kita berfikir, berhubungan dengan orang lain, dan juga memungkinkan memberi makna pada apa yang ditampilkan oleh alam semesta. ${ }^{19}$

Syafethi (2016:9) menjelaskan bahwa Saussure menggambarkan model semiotika itu terdiri dari dua aspek, yakni penanda (signifiant) dan petanda (signifie). Penanda adalah bentuk formal atau citraan visual. Petanda adalah konsep. Saussure tidak menjelaskan tentang pengertian konsep tersebut, namun hanya mengungkapkan bahwa konsep lebih abstrak daripada

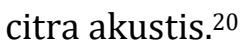

Taylor (1992) menunjukkan bagaimana teori-teori bahasa sejak Locke dapat dipandang sebagai serangkaian jawaban atas argumen skeptis Locke terhadap asumsi umum dari pemahaman intersubjektif. Teori semiotik saat ini umumnya menegaskan bahwa tanda-tanda meng-konstruksi penggunanya (atau "menjadi subjek"), bahwa makna bersifat umum dan pada akhirnya tidak dapat dikendalikan (indeterminate), bahwa pemahaman adalah isyarat praktis daripada keadaan psikologis intersubjektif, dan bahwa kode dan media komunikasi bukan sekadar struktur atau saluran netral untuk transmisi makna, tetapi memiliki ciri-ciri seperti tanda sendiri (kode membentuk konten dan medium itu sendiri menjadi pesan, atau bahkan pesan [McLuhan, 1964:1). ${ }^{21}$

\section{c. Teori Semitotik Roland Barthes}

Roland Barthes (Element of Semiology 1968) mengacu pada Ferdinan de Saussure dengan menyelidiki hubungan penanda dan petanda pada sebuah tanda. Saussure meletakkan tanda dalam konteks bahasa komunikasi manusia tersusun dalam dua bagian yaitu signifier (penanda)

\footnotetext{
18 Hoed, H Benny. 2014. Semiotika dan Dinamika Sosial Budaya. Depok: Komunitas Bambu. h.176.

${ }^{19}$ Sobur, Alex. Analisis Teks Media. h.14.

${ }^{20}$ Setiawan, Kodrat Eko Putro. 2019. Strategi Ampuh Memahami Makna Puisi. Teori Semiotika Michael Riffaterre dan Penerapannya. Cirebon: Eduvision. h.20

${ }^{21}$ Rusyad, Daniel. Landasan Teoritis Tradisi Semiotika Di Dalam Al-Qur'an Paradigma Ilmu Komunikasi Dalam Perspektif Islam.
} 
dan signified (petanda). Signifier yaitu apa yang dikatakan, ditulis, dibaca. Signified adalah pikiran atau konsep (gambaran mental). Barthes mencontohkan dengan seikat mawar. Seikat mawar dapat ditafsirkan untuk menandai gairah (passion), maka seikat kembang itu menjadi penanda dan gairah adalah petanda. Hubungan keduanya menghasilkan istilah ketiga: seikat kembang sebagai sebuah tanda. Sebagai sebuah tanda, adalah penting dipahami bahwa seikat kembang sebagai penanda adalah entitas tanaman biasa. Sebagai penanda, seikat kembang adalah kosong, sedang sebagai tanda seikat kembang itu penuh. ${ }^{22}$

Gagasan Roland Barthes dikenal dengan Two Order of Signification mencakup makna denotasi yaitu tingkat penandaan yang mejelaskan hubungan antara penanda dan petanda yang menghasilkan makna eksplisit, langsung, pasti atau makna sebenarnya sesuai dengan kamus. Sedangkan, makna konotasi yaitu menggambarkan interaksi yang terjadi ketika tanda bertemu dengan perasaan atau emosi dari pembaca serta nilai-nilai yang lahir dari pengalaman kultural dan personal. ${ }^{23}$

Barthes tak sebatas itu memahami proses penandaan, dia juga melihat aspek lain dari penandaan, yaitu "mitos" yang menandai suatu masyarakat. Perspektif Barthes tentang mitos ini menjadi salah satu ciri khas semiologinya yang membuka ranah baru semiologi, yakni penggalian lebih jauh dari penandaan untuk mencapai mitos yang bekerja dalam realitas keseharian masyarakat. Dalam bentuk praksisnya, Barthes mencoba membongkar mitos-mitos modern masyarakat melalui berbagai kajian kebudayaan. ${ }^{24}$ Analisis semiotika bisa diterapkan untuk hampir semua teks media tv, radio, surat kabar, majalah, film, dan foto.

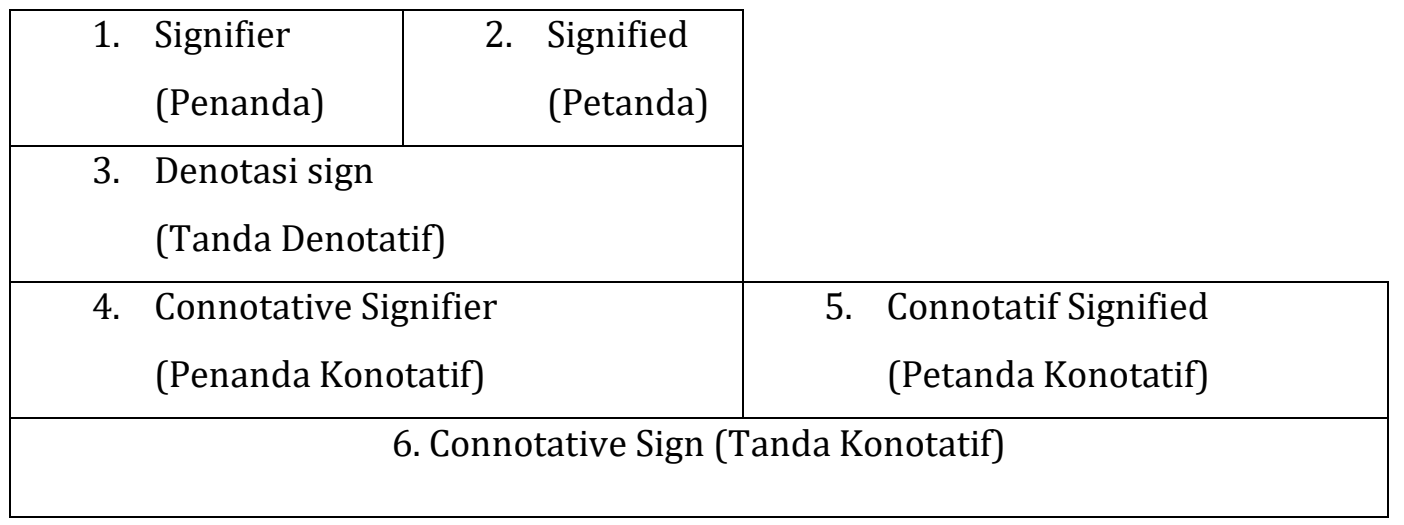

Dari peta Roland Barthes terlihat bahwa tanda denotatif terdiri atas penanda (1) dan petanda (2). Akan tetapi, pada saat bersamaan, tanda denotatif adalah juga penanda konotatif (4). Jadi, dalam konsep Barthes, tanda konotatif tidak sekedar memiliki makna tambahan namun juga

22 Kurniawan. 2001. Semiologi Roland Barthes. Magelang: IndonesiaTera. h.22

23 Fiske, John. 2012. Pengantar Ilmu Komunikasi. Jakarta: Rajawali Pers. h.141.

${ }^{24}$ Kurniawan. 2001. Semiologi Roland Barthes. Magelang: IndonesiaTera. h.22 
mengandung kedua bagian tanda denotatif yang melandasi keberadaannya. Sesungguhnya inilah sumbangan Barthes yang sangat berarti bagi penyempurnaan semiologi Saussure, yang berhenti pada padanan dalam denotatif. Pada dasarnya ada perbedaan antara denotasi dan konotasi dalam pengertian secara umum. Denotasi dimengerti sebagai makna harfiah, makna yang sesungguhnya. Sedangkan konotasi, identik dengan operasi ideologi, makna yang berada diluar kata sebenarnya atau makna kiasan, ${ }^{25}$ yang disebutnya juga sebagai mitos, dan berfungsi untuk mengungkapkan dan memberikan pembenaran bagi nilai-nilai yang dominan yang berlaku dalam suatu periode tertentu. 26

Dalam penelitian ini objek atau tanda yang akan diamati adalah komunikasi yang dilakukan oleh Dinas Kesehatan Kota Semarang melalui sosial media Instagram pada saat kondisi Pandemi Covid-19 yang identik dengan upaya memutus rantai penyebaran virus dan mendukung program Vaksinasi. Peneliti akan menganalisis objek dengan menggunakan pendekatan semiotika Roland Barthes.

1. Video berdurasi 31 detik pada akun Instagram resmi @dkksemarang yang di upload pada tanggal 24 April 2021.

\begin{tabular}{|l|l|}
\hline Makna Denotasi & Makna Konotasi \\
\hline & $\begin{array}{l}\text { Video parodi kampanye menggunakan } \\
\text { masker diambil dari cuplikan drama } \\
\text { korea berjudul Vincenzo yang dibintangi } \\
\text { aktor Song Joong-Ki. Video tersebut } \\
\text { menggunakan teknik penyulihan suara } \\
\text { atau dubbing (proses merekam atau } \\
\text { menggantikan suara untuk suatu tokoh } \\
\text { karakter). } \\
\text { Komunikasi disampaikan secara verbal } \\
\text { yaitu dengan berbicara langsung. Disertai } \\
\text { dengan pesan nonverbal: jari menujuk } \\
\text { sebagai (penanda) yang kemudian } \\
\text { ditafsirkan sebagai (petanda) marah. } \\
\text { Dari tanda tersebut dapat disimpulkan } \\
\text { bahwa Dinas Kesehatan Kota Semarang } \\
\text { menampilkan bentuk peringatan tegas } \\
\text { bagi masyarakat yang abai terhadap } \\
\text { protokol kesehatan terutama } \\
\text { penggunaan masker pasca vaksin. Hal } \\
\text { tersebut ditunjukkan dengan tanda seru } \\
\text { pada kalimat "mbok pikir nek wes vaksin ki } \\
\text { kebal covid??!!!". Tanda seru dan ekspresi }\end{array}$ \\
\hline kandhani ojo bosen nganggo masker
\end{tabular}

25 Saifullah, Aceng Ruhendi. 2018. Semantik dan Dinamika Pergulatan Makna. Jakarta Timur: Bumi Aksara. h.72.

${ }^{26}$ Herwedo, Rionaldo. 2014. Analisis Semiotik Represenatsi Perilaku Masyarakat Jawa Dalam Film Kala. Wacana Volume XIII No.3 h.234. 
Teks dalam video menggunakan bahasa Jawa:

"Lur Sedulur...kandhani ojo bosen nganggo masker, dinggo masker e sing bener, paham opo ora to...mbok pikir nek wes vaksin ki kebal covid???!!! Yo Oraa...."

Dalam bahasa Indonesia video tersebut mengatakan:

"Saudara-saudara... dikasih tahu jangan bosan memakai masker, pakai maskernya yang benar, mengerti apa tidak...kamu pikir kalau sudah vaksin itu kebal covid???!!! Ya Tidaak..." marah, mengisyaratkan seruan atas kesungguhan bahaya penularan Covid19.

2. Gambar Program Vaksin Lansia yang diupload oleh akun resmi Instagram @dkksemarang pada tanggal 7 Juni 2021.

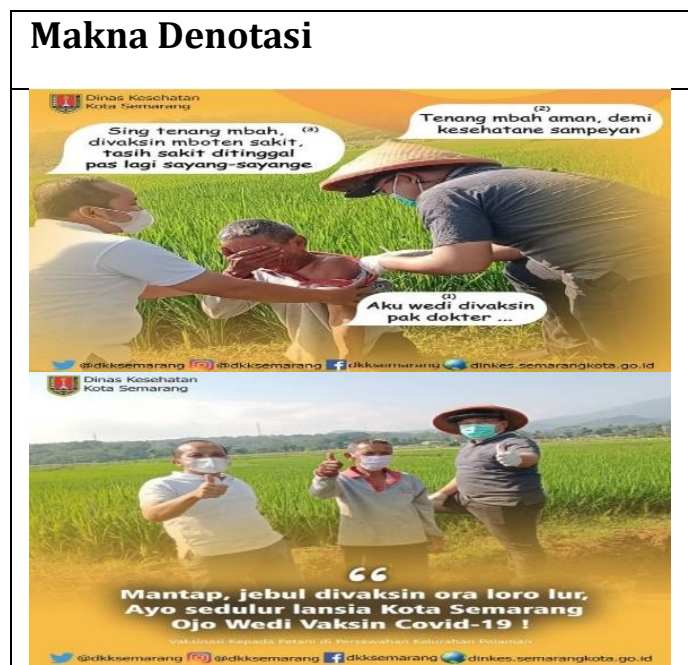

Gambar 1 tertulis:

"Aku wedi divaksin pak dokter..

"Tenang mbah aman, demi kesehatane sampeyan."

"Sing tenang mbah, divaksin mboten sakit, tasih sakit ditinggal pas lagi sayangsayange."

Gambar 2:

"Mantap, jebul divaksin ora loro lur, Ayo sedulur lansia kota Semarang ojo wedi Vaksin Covid-19!"

Dalam bahasa Indonesia:

"saya takut divaksin pak dokter...

"Tenang Mbah aman, untuk kesehatan mu."

"Tenang mbah, divaksin tidak sakit, masih sakit ditinggal kalau lagi sayang-sayangnya."

\section{Makna Konotasi}

Petugas kesehatan menggunakan pakaian bebas melakukan vaksin terhadap lansia di area persawahan. Orang tua yang divaksin terlihat menutup wajah dengan telapak tangan sebagai (penanda) ketakutan melihat jarum suntik (petanda). Strategi upaya jemput bola ini dilakukan agar warga lansia proaktif dalam menyelesaikan masalah pandemi Covid-19.

Lansia merupakan kelompok rentan terpapar virus karena sistem imun yang sudah menurun serta penyakit kronis dapat meningkatkan risiko terkena Covid-19.

Komunikasi yang hendak disampaikan dalam gambar tersebut adalah Dinas Kesehatan Kota Semarang terus berupaya meingkatkan cakupan vaksinasi pada lansia, salah satunya dengan mendatangi langsung para petani lansia di persawahan untuk vaksinasi Covid19 demi lansia Kota Semarang tetap sehat.

Terlihat dalam gambar Petugas Kesehatan dan Lansia mengacungkan jempol, sebagai upaya mengajak warga lansia lainnya melakukan vaksinasi Covid-19. 
"Mantap, ternyata divaksin tidak sakit saudara, Ayo saudara Lansia kota Semarang jangan takut vaksin Covid-19!."

Makna mitos dari video dan gambar di atas terdapat realitas bahwa masyarakat mempunyai tingkat kepercayaan yang berbeda-beda terhadap vaksin covid-19. Program Vaksinansi dengan sasaran menciptakan herd imunity untuk melawan virus corona terus dilakukan. Namun para ahli kedokteran mengatakan jika vaksin yang disuntikkan sampai saat ini belum menjamin 100\%, hanya saja vaksin dapat mengurangi resiko sakit hingga mengurangi angka kematian, selain itu vaksin sangat berguna bagi tenaga kesehatan yang berada di garda terdepan, serta para lansia yang berusia di atas 60 tahun dan untuk mereka yang menderita penyakit bawaan atau komorbid. ${ }^{27}$ Maka setelah vaksinasi warga wajib tetap menjaga protokol kesehatan. Karena bukan berarti setelah vaksin, kekebalan tubuh menjadi kuat langsung bebas berkerumun dan melupakan protokol kesehatan 5M yaitu memakai masker, menjaga jarak, mencuci tangan, menghindari kerumunan, dan mengurangi mobilitas.

\section{PENUTUP}

Dalam kaitannya dengan objek penelitian, teks merupakan suatu konstruksi dari unsur tandatanda. Dalam tradisi semiotika, komunikasi pada intinya dipandang sebagai mediasi atau pertukaran tanda-tanda secara intersubjektif. Sebagai teori penafsiran, semiotik tidak sekedar menafsirkan teks, memperlakukan teks sebagai teks, tetapi membuat teks berbicara, bahkan tentang hal di luar dirinya. Pada dasarnya manusia memiliki kemampuan untuk mencari makna pada setiap gejala sosial yang terjadi di sekitarnya. Dalam tradisi semiotika, komunikasi pada intinya dipandang sebagai mediasi atau pertukaran tanda-tanda secara intersubjektif. Komunikasi menjelaskan dan mengembangkan penggunaan bahasa dan sistem-sistem tanda lainnya dalam bentuk pertukaran (mediasi) antar perspektif yang bervariasi. Problematika komunikasi dalam paradigma Semiotika merupakan problematika representasi dan transmisi makna, dalam hal terjadinya gap antara subjektivitas yang coba di atasi melalui penggunaan sistem tanda yang disepakati.

27 https://www.tribunnews.com/corona/2021/04/08/apakah-setelah-divaksin-tubuh-dapatkebal-dari-virus-covid-19-begini-kata-dokter diakses pada tanggal 21 Juni 2021. 


\section{DAFTAR PUSTAKA}

Ali, Romdhoni. 2004. Ushul al-Fiqh dan Semiotika Post-Strukturalis (Koran Amanat IAIN Walisongo, edisi 102/November 2004)

Fiske, John. 2012. Pengantar Ilmu Komunikasi. Jakarta: Rajawali Pers.

Hoed, H Benny. 2014. Semiotika dan Dinamika Sosial Budaya. Depok: Komunitas Bambu.Moleong, Lexy J. 2002. Metode Penelitian Kualitatif. Bandung: PT Remaja Rosdakarya.

Heridansyah, Haris. 2012. Metode Penelitian Kualitatif untuk Ilmu-Ilmu Sosial. Jakarta: Salemba Humanika.

Herwedo, Rionaldo. 2014. Analisis Semiotik Represenatsi Perilaku Masyarakat Jawa Dalam Film Kala. Wacana Volume XIII No.3 h.234.

Kurniawan. 2001. Semiologi Roland Barthes. Magelang: IndonesiaTera.

Lantowa, Jafar. 2017. Semiotika Teori, Metode, dan Penerapannya dalam Penelitian Sastra. Yogyakarta: Deepublish. h.1.

Rahayu, Surtiati Hidayat. Semiotik dan Bidang Ilmu.

Romdhoni, Ali. 2016. Semioltik Metodologi Penelitian. Depok: Literatur Nusantara.

Rusyad, Daniel. Landasan Teoritis Tradisi Semiotika Di Dalam Al-Qur'an Paradigma Ilmu Komunikasi Dalam Perspektif Islam.

Saifullah, Aceng Ruhendi. 2018. Semantik dan Dinamika Pergulatan Makna. Jakarta Timur: Bumi Aksara.

Setiadi, Gatut, and Nurma Yuwita. "PENGEMBANGAN MODUL MATA KULIAH BAHASA INDONESIA MENGGUNAKAN MODEL ADDIE BAGI MAHASISWA IAI SUNAN KALIJOGO MALANG". Akademika : Jurnal Manajemen Pendidikan Islam 2, no. 2 (December 3, 2020): 200217. Accessed April 2021. https://ejournal.iaiskjmalang.ac.id/index.php/akad/article/view/207.

https://www.tribunnews.com/corona/2021/04/08/apakah-setelah-divaksin-tubuh-dapatkebal-dari-virus-covid-19-begini-kata-dokter diakses pada tanggal 21 Juni 2021.

Setiawan, Kodrat Eko Putro. 2019. Strategi Ampuh Memahami Makna Puisi. Teori Semiotika Michael Riffaterre dan Penerapannya. Cirebon: Eduvision.

Stokes, Jane. 2006. How To Do Media and Cultural Studies: Panduan untuk Melaksanakan Penelitian dalam Kajian Media dan Budaya. Bandung: Mizan Media Utama. Hal 76.

Yasraf, Amir Piliang. Semiotika sebagai Metode dalam Penelitian Desain, dalam Christomy dan Untung Yuwono, 